\title{
A CONTRASTIVE ANALYSIS OF PERSIAN AND ENGLISH VOWELS AND CONSONANTS
}

\author{
Hamzeh Moradi* \\ Nanfang College of Sun Yat-sen University, Guangzhou, China \\ Jianbo Chen \\ Sun Yat-sen University, Guangzhou, China \\ *Corresponding author
}

Moradi, H. \& Chen, J. (2018). A contrastive analysis of Persian and English vowels and consonants. In Lege artis. Language yesterday, today, tomorrow. The journal of University of SS Cyril and Methodius in Trnava. Warsaw: De Gruyter Poland, 2018, III (2), December 2018, p. 105-131. DOI: 10.2478/lart-2018-0016 ISSN 2453-8035

\begin{abstract}
The study presents a contrastive analysis of two distinct sound systems, namely, those of Persian and English. It provides a descriptive analysis and a contrastive study of consonants and vowels of these languages, expatiating on the similar and dissimilar features of the two sound systems. Dissimilarities are especially important since they may result in production of deviant sounds by foreign language learners.
\end{abstract}

Keywords: contrastive analysis, sound system, phonological feature, consonant, vowel, bilingual speaker.

\section{Introduction}

Contrastive analysis (CA) has been extensively used in linguistics and language teaching (Brown 2000; Fasold \& Connor-Linton 2006; Ranta 2010; Yule 2006). In particular, it is applied in the comparative synchronic investigation of two or more languages or language varieties. Though the primary focus of CA is on differences, it usually concerns both differences and similarities of the languages under consideration. 
The focus on differences is characteristic for the study of linguistic interference, that is the impact of one language on another. As Khalifa (2018) notes, such impact can be positive or negative; in the latter case, it is called negative transfer, which is defined as brining a wrong linguistic feature from the mother tongue to the second, or target, language.

Kabak and Idsardi (2007) investigate the difficulties that Korean learners of the English language experience in mastering English consonant clusters. They observe that restrictions of the syllable structure cause perceptual epenthesis in the target language. In his study of errors and difficulties of the Chinese learners of English in pronouncing consonant clusters, Chang (2004) proceeds from the contrastive analysis hypothesis, pointing out that the syllable structure of Chinese has just one consonant in the onset, while the English language has three consonants in the onset. Hence, due to this complexity of the syllable structures of Chinese, on one hand, and English, on the other, Chinese learners of English face the challenge of their first language interference. The results of this study have also revealed various types of errors including epenthesis, deletion of the second sound of a consonant cluster in the initial position, and processing a cluster as a single unit.

Fernandez and Banguis (2018) assert that a facilitative language transfer can occur when two languages have similar linguistic features. In other words, language transfer can be positive and facilitative where the first language (L1) and the second language (L2) possess identical linguistic characteristics. CA focuses on the investigation of morphology and phonology of the languages or language varieties; investigation of the social context of language functioning is not the major concern of CA. In other words, CA does not consider pragmatic or socio-pragmatic aspects affecting linguistic performance, or language use.

Cheng (2018) describes language as a symbolic system that consists of sounds, or voice, vocabulary, and grammar; it actually functions as a sort of communicative tool in the 
social context. According to Goodwin (2001: 117), "pronunciation is the language feature that most readily identifies speakers as non-native".

There are many studies focusing on CA of intonation in different languages (Deterding 2018; Eghlidi 2016; Esteve-Gibert et al. 2018; Forsberg \& Abelin 2018; Hayati 2005; Hellmuth 2018; Peters 2018; Puga et al. 2018; Tsui \& Tong 2018). There are several studies of the Persian language (Eghlidi 2016; Hayati 1996, 1998, 2005; Soltani 2007; Yarmohammadi 2002) that focus specifically on contrasting the intonation patterns of Persian and English. For example, Soltani (2007), with the help of spectrographic analysis of recorded speech sounds of Persian-English bilingual speakers, analyses the intonation patterns of Persian and English in the contrastive perspective. Mahjani (2003) investigates the intonation patterns and prosodic features of the Persian language in detail.

Yarmohammadi (2002) in his book, which focuses mainly on the linguistic components of Persian and English, contrasts the intonation patterns of these two languages. Moradi (2012) investigates sound deletion in colloquial Persian. In his study, he draws a distinction between colloquial Persian and formal Persian, asserting that "among the differences that distinguish colloquial Persian from its formal variety are deletion and assimilation of sounds" (ibid., 109). However, less research has been done on contrasting the sound systems of Persian and English (consonant, vowels, diphthongs, and phonological features).

With the help of CA of Persian and English, structural dissimilarities between these languages are established; afterwards these characteristics are studied carefully in order to find out potential difficulties for language users or language learners of English as a second or foreign language. These difficulties can cause language interference, which is the influence of a certain linguistic feature on another feature, either at the individual level or at the level of the speech community. 
Our paper aims at providing a qualitative analysis of vowels and consonants in English and Persian, presenting a CA of vowels and consonants of these languages. The main focus is on contrasting phonological features of the two sound systems, which may result in production of deviant phonetic forms by Iranian learners of English. In addition, the authors investigate the extent to which separate phonological features of Persian and English may affect pronunciation of English sounds, thus making an attempt to identify the main problematic areas that cause pronunciation errors and result in deviant phonetic forms produced by Persian-English bilingual speakers.

\section{Definition of key terms}

This section provides the definition of key terms related to the phonological CA and highlights the main differences between them.

\subsection{Bartholomae's law}

Bartholomae's law, discovered by Bartholomae (1883), is a sound law in IndoEuropean language family affecting primarily Indo-Iranian languages. It concerns the sound change that occurs in Indo-Iranian languages in consonant clusters of voiced aspirated plosives and voiceless non-aspirated plosives. The root final aspirated voiced plosive is actually deaspirated. It extends voice and shifts aspiration to the following plosive sound (ibid.).

\subsection{On-glide vs. off-glide}

These terms refer to the beginning vs. the end point of a speech sound articulation. They explain the movement of the articulator from or towards its resting position. In on-glide or off-glide, the speech sound is formed with the pulmonary air flow. Distinction is usually drawn between a strong on- and off-glides or weak ones. With the exception of affricated stops, post-aspirated stops, glottal plosives and postnasalized plosives, most of speech sounds have weak off-glides. However, strong onglides occur in non-prenasalized and non-preaspirated stops (Moulton 1962). 


\subsection{Aspirated vs. un-aspirated}

Aspirated sounds are the ones released with a kind of a puff of air when articulated (Crystal 2008). Examples of such sounds, which are called voiceless plosives, can be $/ \mathrm{k} /, / \mathrm{p} /$ and $/ \mathrm{t} /$ that are pronounced with the $/ \mathrm{h} /$ sound after them, as $/ \mathrm{k}^{\mathrm{h}} /, / \mathrm{p}^{\mathrm{h}} /, / \mathrm{t}^{\mathrm{h}} /$. In case there is no $/ \mathrm{h} /$ sound after these stops, they are un-aspirated. In other words, there is no puff of air after them.

\subsection{Released vs. un-released}

When a stop is fully articulated, it is released, otherwise it is an un-released stop sound, for instance /k-/. The International Phonetic Alphabet (IPA) depicts an un-released stop with a corner diacritic symbol, i.e. [], for example [P] in 'type' (Knowles 1987). Thus, in the Persian language, the sounds $/ \mathrm{k} /, / \mathrm{t} /$, and $/ \mathrm{p} /$ respectively are un-released stops in the following examples: Teke /teke/, which means 'piece', Tape /tæpe/, which means 'hill', and finally Albate /ælbæte/, which means 'of course'.

\subsection{Implosive vs. plosive}

Implosive as a common term used in phonetic classification of consonants based on the manner of articulation (Crystal 2008). An implosive is a non-nasal stop sound that is produced with a pharyngeal airflow mechanism when the larynx is lower than its usual position and the glottis is nearly closed. In contrast to the implosives, a plosive is a non-nasal stop sound that has a plutonic sound mechanism. As mentioned by Crystal $(1969,2008)$, a plosive is a speech sound that is produced when the airstream is blocked for a short time and suddenly released, such as $/ \mathrm{p} /, / \mathrm{t} / \mathrm{/} / \mathrm{b} /, \mathrm{d} /$.

\subsection{Assimilation vs. dissimilation}

Assimilation is a phonological process, in which a specific speech sound with particular phonological features changes in order to become more similar to the sound that follows or precedes it. For example, im- as a negative prefix in English in words starting with a bilabial stop, such as possible-impossible and in Persian words such as Shanbe-Shambe, as can be seen in the following Persian example: Shanbe, which 
means 'Saturday', the sound /n/ in Shanbe, which is an alveolar sound, changes into /n/ (Shambe), which is a bilabial sound. This assimilation occurs because of the phonological features of the sound after $/ \mathrm{n} /$, i.e. $/ \mathrm{b} /$, which is a bilabial sound. Such kind of assimilation is quite widespread in spoken Persian. In contrast to assimilation, dissimilation is a process in which a similar sound changes and differentiates itself from another similar sound in order to be clearer. In other words, similar sounds in a word become less identical in dissimilation process.

It should be mentioned that assimilation has various facets and, accordingly, several types of assimilation can be distinguished. Vennemann (1972) asserts that assimilation can be: (1) a matter of a place of articulation, for example, $/ \mathrm{n} /$ in incomplete is pronounced as [ $\mathrm{y}]$, or the manner of articulation, for example, the phrase good night is pronounced as /gon nait/; or in the Persian language bad tar is pronounced as /bæt tær/ in colloquial speech and the glottal state or voicing, for instance, the plural morpheme $-s$ in words like cats /kæts/ and dogs /dpgz/; (2) based on the direction of influence. In a sound sequence, a distinction is made between progressive, regressive and coalescent (or reciprocal) assimilation. Progressive, or perseverative, assimilation occurs when the preceding sound affects the following one and brings a change into it, for example, the difference in pronouncing /s/ in cats and $\operatorname{dog}_{s}$, as mentioned above. Regressive assimilation, or anticipatory coarticulation, occurs when the sound that follows affects the preceding sound and brings about a change in the latter. In other words, the preceding sound takes on a feature or several features of the sound that follows and adapts itself to the latter. For example, /s/ in swim undergoes the rounding of lips, as a result of anticipating the rounding of lips for /w/. Assimilation is considered to be reciprocal when there is a mutual or bidirectional influence of sounds upon each other or, in other words, when a mutual adaption occurs; (3) a distinction between complete and partial assimilation; if the sounds are distinguished by just one phonological feature, it is a complete, or total, assimilation. However, partial, or incomplete, assimilation refers to the change of just one of several phonological features. For instance, the phrase ten bikes, which in colloquial speech may be pronounced as /tem barks/; in this 
particular example, assimilation is partial, because the $/ \mathrm{n} /$ has adopted only one feature of the following sound, i.e. /b/, and that is the bilibiality feature of $/ \mathrm{b} /$, however it has not taken on the plossiveness feature of the $/ \mathrm{b} /$ sound. On the other hand, in the phrase ten mice, in colloquial speech /tem mars/, assimilation is complete, or total, because /n/ is now completely identical to $/ \mathrm{m} /$; in addition, if the sound change is due to the influence of adjacent sounds, it is the case of contiguous, or contact, assimilation. Otherwise, distant assimilation occurs, which presupposes that the two sound that undergo change are not adjacent.

\subsection{Palatalization}

Palatalization is a general term in phonology, which refers to any sort of articulation that involves the tongue movement or raise towards the hard palate, or roof of the mouth (Crystal 2008). Sometimes consonant palatalization causes the surrounding sounds to change by assimilation. This kind of assimilation, or coarticulation, occurs when two successive sounds come together to produce a sound that has peculiar features from both basic sounds. In other words, it is a change in the place of articulation through assimilation towards the hard palate.

A consonant can be palatalized if the middle or back part of the tongue raises towards the roof of the mouth. For example, /k/, /g/ in the Persian language are palatalized, as indicated in the flowing examples:
a) keshvar /keshvær/ "country"
b) kam $\quad / \mathrm{kæm} / \quad$ "little"
c) gerye /gerje/ "cry"
d) gavazn /gævæzn/ "deer"

\subsection{Retroflex}

Retroflex is a speech sound that is distinguished by the place of articulation, which is post-alveolar. For production of a retroflex, the tip of the tongue moves or curls towards the back part of the alveolar ridge area (Crystal 2008). 


\subsection{Flap vs. trill}

A speech sound that is produced with a kind of flapping motion as it passes by its obstruction is called a flap; the production of this speech sound is with a single striking motion of the tip of the tongue towards and upwards against the hard-front palate or alveolar ridge (Knowles 1987). A trill is produced when the tongue vibrates rapidly against the roof of the moth in a series of quick taps. Some accents of English, such as Welsh and Scots, use a trilled $/ r /$ sound. For example, $\mid r /$ in some cases of Scottish English is a trill, e.g., rip (Richards \& Schmidt 2013).

\subsection{Dental}

In the production of dentals, the front part of the tongue touches the back of the upperfront teeth (Catford 1988). In a broader sense, it also includes inter-dental and labiodental sounds. For example, $/ t /$ and $/ d /$ in the Persian language, as $/ t /$ in $t a r s u$, which means 'coward', /d/ in darya, which means 'sea', etc. It should be mentioned that in contrast to English, these sounds are dental-alveolar in Persian.

\subsection{Labio-dental}

The articulators and place of articulation for the production of these speech sounds are lips (labial) and teeth (dental), e.g., /f/ and /v/ in Persian, such as feshar, which means 'pressure', or varzesh, which means 'sport'.

\subsection{Dental-alveolar}

These sounds in Persian include /d/, /t/, /s/, and /z/, which have dental-alveolar as their articulation, while the same speech sounds in English are alveolar. See the following examples:
a) donya
/donja/
"world"
b) tanha /tænha/ "alone"
c) sard /særd/ "cold"
d) zard /zærd/ "yellow" 


\subsection{Front vs. back}

The production of vowels is based on the tongue shape and its position in the mouth, e.g., front, back, high, or low vowels. Considering /æ/ and /i:/ vowels in English, as mentioned by Roach (1991), the difference between them is the height of the tongue and respectively they are relatively open and closed vowels. In front vowels, the tongue is positioned forward in the mouth, for example, /æ/, which is a relatively front vowel in Persian. Roach (ibid., 12) observes that "by changing the shape of the tongue we can produce vowels in which a different part of the tongue is the highest point". According to this description, when a back vowel is produced, in contrast to a front one, the back of the tongue is raised towards the roof of the mouth, and the back of the tongue, therefore, is the highest point, for example, /p/ in Persian.

\subsection{Open vs. close syllables}

If a syllable ends in a vowel, it is called an open syllable; if it ends in a consonant, it is called a closed syllable. A syllable itself can be divided into three parts, (1) the onset: the beginning of the syllable, for example, $\mathbf{C V C},(2)$ the nucleus, or peak: the central part of the syllable that consists of vowels, for example, CVC, and (3) the coda: the end of the syllable, for example, CVC. For instance, the syllable structure for the Persian word sag/sæg/, which means 'dog', is CVC in which/s/ is the onset, /æ/, which is a vowel, is the nucleus, and finally /g/ is the coda.

\subsection{Vowel harmony}

It can be defined as a kind of assimilation, or modification, of a vowel pronunciation in a word so that one vowel harmonizes with another vowel.

\section{Syllable structure of Persian and English}

Before going further, it is important to consider syllabic features of Persian. The distribution of consonants (C) and vowels (V) is not the same in Persian and English (see Table 1), as in English the distribution of consonants can be VC, VCC, VCCC, $\mathrm{CV}, \mathrm{CVC}, \mathrm{CVCC}, \mathrm{CCV}, \mathrm{CCVC}, \mathrm{CCVCC}, \mathrm{CCVCCC}, \mathrm{CCVCCCC}, \mathrm{CCCV}, \mathrm{CCCVC}$, 
CCCVCC, CCCVCCC, CCCVCCCC; in contrast to English, in the Persian language there are three major types of syllable structures including $\mathrm{CV}, \mathrm{CVC}$, and $\mathrm{CVCC}$; in other words, CV (C) (C). Table 1 below illustrates the syllable structures of Persian and English.

Table 1. Syllable structure of English and Persian

\begin{tabular}{|l|l|}
\hline \multicolumn{2}{|c|}{ Syllable Structure } \\
\hline English & $(\mathrm{C})(\mathrm{C})(\mathrm{C}) \mathrm{V}(\mathrm{C})(\mathrm{C})(\mathrm{C})(\mathrm{C})$ \\
\hline Persian & $(\mathrm{C}) \mathrm{V}(\mathrm{C})(\mathrm{C})$ \\
\hline
\end{tabular}

As defined by Roach (1991), a syllable is a phonological unit that consists of one vowel, which is known as the nucleus, or the peak, and preceded by the onset, which is a consonant or a consonant cluster, and followed by a consonant or a consonant cluster known as the coda. As seen in Table 1, in the English language it is possible to have a consonant cluster, made of as many as three consonants, before the vowel and four consonants after the vowel as the coda; the possibility of occurrence of a syllable in English, therefore, can be illustrated as (C) (C) (C) V (C) (C) (C) (C).

However, as illustrated in Table 1, in contrast to English, there is no consonant clustering in the onset position in Persian. The syllabic structure of Persian is composed of one optional onset, which is a consonant, the obligatory nucleus, which is a vowel, and an optional coda, consisting of a consonant or a consonant luster.

According to the distribution of consonants and vowels in Persian, canonical forms of syllable structures can be identified, for example, CV, CVC, and finally CVCC. To clarify the points, Table 2 below provides some examples of Persian syllable structures. 
Table 2. Examples of Persian syllabic structure

\begin{tabular}{|c|c|c|c|}
\hline \multicolumn{2}{|c|}{ Persian Word } & \multirow{2}{*}{$\begin{array}{c}\text { Meaning } \\
\mathrm{We}\end{array}$} & \multirow{2}{*}{$\begin{array}{c}\text { Syllabic Structure } \\
\mathrm{CV}\end{array}$} \\
\hline ما & $/ \mathrm{ma} /$ & & \\
\hline سع س & /sæg/ & Dog & $\mathrm{CVC}$ \\
\hline سرد & /særd/ & Cold & CVCC \\
\hline خسته & /xæs.te/ & Tired & CVC.CV \\
\hline شناخت & / ee.naxt/ & Cognizance & CV.CVCC \\
\hline
\end{tabular}

As is seen in Table 2, in Persian, in contrast to English, clustering of consonants can only take place at the end of a syllable or, in other words, in the coda. Therefore, Iranian learners of English may find it very difficult to pronounce initial English consonant clusters; as Keshavarz (2001) mentions, they insert a vowel before or between a consonant cluster to make its pronunciation easier, which in linguistics is known as epenthesis. He remarks that in order to simplify the pronunciation of consonant clusters at the end of a syllable in English, Iranian learners of English sometimes delete one of the consonants of the final cluster made of three consonants or more. In Persian, there is no word with three or more consonants in the final consonant cluster. In other words, only two consonants are allowed in a final consonant cluster in the Persian language; this is in line with Salmani-Nodoushan and Birjandi (2005), who asserts that the Persian language does not have more than two consonants in final consonant clusters or clusters in the coda.

\section{Persian and English sound systems}

As mentioned above, the present study is a descriptive representation of the sound systems of Persian and English. It compares two distinct systems of speech sounds with their peculiar phonological features; it aims to identify the dissimilar phonemes and phonemic inventories of the two languages, to investigate if they have distinct phonetic structures and values, and to compare the distribution of single phonemes with regards to their positions. Figure 1 represents the International Phonetic Alphabet (IPA) Chart, a standardized sound representation of spoken language, which is a significant tool for 
language learners, teachers, researchers and linguists to capture the speech sounds of any language and it helps them pronounce any word in any language; the subsequent tables parallel the sound systems of Persian and English.

THE INTERNATIONAL PHONETIC ALPHABET (revised to 2005)

CONSONANTS (PULMONIC)

(1) 2005 IPA

\begin{tabular}{|c|c|c|c|c|c|c|c|c|c|c|c|}
\hline & Bilabial & Labiodental & Dental & Alveolar & Postalveolar & Retroflex & Palatal & Velar & Uvular & Pharyngeal & Glottal \\
\hline Plosive & $\mathrm{p} \quad \mathrm{b}$ & & & $\mathrm{t} d$ & & t $d$ & c $\mathrm{f}$ & $\mathrm{kg}$ & q G & & $?$ \\
\hline Nasal & $\mathrm{m}$ & $\mathrm{m}$ & & $\mathrm{n}$ & & $\eta$ & $\mathrm{n}$ & $\eta$ & $\mathrm{N}$ & & \\
\hline Trill & B & & & $r$ & & & & & $\mathrm{R}$ & & \\
\hline Tap or Flap & & $r$ & & ᄃ & & r & & & & & \\
\hline Fricative & $\phi \beta$ & f $v$ & $\theta \quad \partial$ & S Z & $\int 3$ & $\begin{array}{ll}S & Z\end{array}$ & ç j & $\mathrm{X} \gamma$ & $\chi$ в & h $\mathrm{S}$ & h $\mathrm{h}$ \\
\hline \begin{tabular}{|l|}
$\begin{array}{l}\text { Lateral } \\
\text { fricative }\end{array}$ \\
\end{tabular} & & & & 43 & & & & & & & \\
\hline Approximant & & $v$ & & I & & $\mathrm{t}$ & $\mathrm{j}$ & ய & & & \\
\hline \begin{tabular}{|l|} 
Lateral \\
approximant
\end{tabular} & & & & 1 & & l & $\Lambda$ & $\mathrm{L}$ & & & \\
\hline
\end{tabular}

Where symbols appear in pairs, the one to the right represents a voiced consonant. Shaded areas denote articulations judged impossible.

CONSONANTS (NON-PULMONIC)

\begin{tabular}{|c|c|c|c|c|}
\hline & Clicks & Voiced implosives & & Ejectives \\
\hline$\odot$ & Bilabial & 6 Bilabial & , & Examples: \\
\hline & Dental & d Dental/alveolar & $\mathrm{p}^{\prime}$ & Bilabial \\
\hline 1 & (Post)alveolar & f Palatal & $t^{\prime}$ & Dental/alveolar \\
\hline$\neq$ & Palatoalveolar & $\oint$ velar & $\mathrm{k}^{\prime}$ & Velar \\
\hline || & Alveolar lateral & G Uvular & $\mathrm{S}^{\prime}$ & Alveolar fricative \\
\hline
\end{tabular}

VOWELS

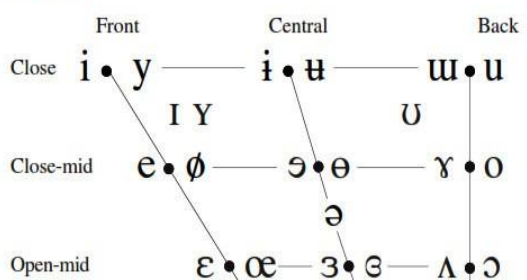

OTHER SYMBOLS

\begin{tabular}{|c|c|c|c|c|}
\hline$M$ & Voiceless labial-velar fricative & 67 & Alveolo-palatal fricatives & Open \\
\hline W & Voiced labial-velar approximant & $I$ & Voiced alveolar lateral flap & \\
\hline 4 & Voiced labial-palatal approximant & † & Simultaneous $\int$ and $\mathbf{X}$ & \\
\hline $\mathrm{H}$ & Voiceless epiglottal fricative & & & \\
\hline$q$ & Voiced epiglottal fricative & $\begin{array}{l}\text { Affricat } \\
\text { can be } r \\
\text { joined } b\end{array}$ & $\begin{array}{l}\text { es and double articulations } \\
\text { epresented by two symbols } \\
\text { by a tie bar if necessary. }\end{array}$ & ts \\
\hline
\end{tabular}

DIACRITICS Diacritics may be placed above a symbol with a descender, e.g. $\stackrel{\circ}{\eta}$

\begin{tabular}{|c|c|c|c|c|c|}
\hline 0 & Voiceless & $\mathrm{n}_{0} \mathrm{~d}_{0}^{\mathrm{d}}$ & .. & $\begin{array}{lll}\text { Breathy voiced } & \mathrm{b} & \mathbf{a}\end{array}$ & $\mathrm{t}_{n} \underset{n}{\mathrm{~d}}$ \\
\hline & Voiced & $\underset{v}{S} t$ & $\sim$ & Creaky voiced $\quad \underset{\sim}{\mathrm{b}} \underset{\sim}{\mathrm{a}}$ & $\mathrm{t} d$ \\
\hline $\mathrm{h}$ & Aspirated & $\mathrm{t}^{\mathrm{h}} \mathrm{d}^{\mathrm{h}}$ & $r$ & Linguolabial $\quad \underset{\sim}{\mathrm{t}} \quad \underset{\sim}{\mathrm{d}}$ & $\mathrm{t} \mathrm{d}$ \\
\hline , & More rounded & ? & w & Labialized $\quad \mathrm{t}^{\mathrm{W}} \mathrm{d}^{\mathrm{W}}$ & $\sim$ Nasalized \\
\hline$c$ & Less rounded & ? & $\mathrm{j}$ & Palatalized $\quad \mathrm{t}^{\mathrm{j}} \quad \mathrm{d}^{\mathrm{j}}$ & $\mathrm{n}$ Nasal release \\
\hline+ & Advanced & $\underset{+}{\mathrm{U}}$ & $\mathrm{Y}$ & velarized $\quad t^{\gamma} d^{\gamma}$ & 1 Lateral release \\
\hline- & Retracted & $\underline{\mathrm{e}}$ & S & Pharyngealized $\mathrm{t}^{\mathrm{f}} \mathrm{d}^{\mathrm{S}}$ & ${ }^{7}$ No audible release $\quad \mathrm{d}^{\top}$ \\
\hline •. & Centralized & $\ddot{e}$ & $\sim$ & Velarized or pharyngealized $\mathrm{t}$ & \\
\hline$x$ & Mid-centralized & $\stackrel{x}{e}$ & $\perp$ & Raised & $=$ voiced alveolar fricative) \\
\hline 1 & Syllabic & $n_{1}$ & $T$ & Lowered & = voiced bilabial approximant) \\
\hline n & Non-syllabic & en & -1 & Advanced Tongue Root & \\
\hline 2 & Rhoticity & $\partial a r$ & r & Retracted Tongue Root & \\
\hline
\end{tabular}

æ

$\mathrm{a} \cdot \mathrm{E}-\mathrm{a} \cdot \mathrm{D}$

Where symbols appear in pairs, the one to the right represents a rounded vowel.

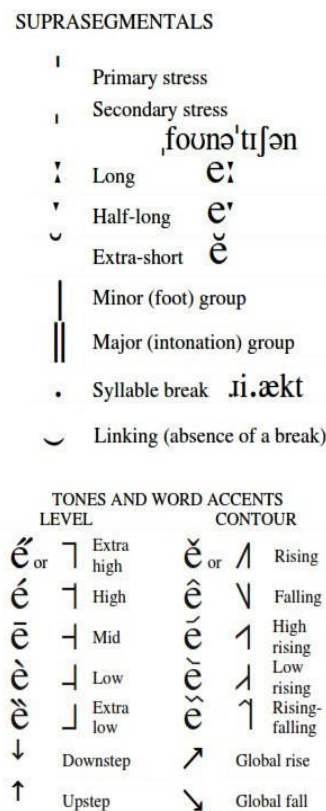

Figure 1. The International Phonetic Alphabet (Melchers \& Shaw 2013) 
Table 3 presents contrastive phonemic features of Persian and English consonants.

Table 3. Contrastive phonemic features of English and Persian consonants

\begin{tabular}{|c|c|c|c|c|c|c|c|c|c|c|c|c|c|c|c|c|c|c|c|}
\hline \multirow{2}{*}{\multicolumn{2}{|c|}{$\begin{array}{l}\quad \text { Place of } \\
\text { Articulation } \\
\text { Manner of } \\
\text { Articulation }\end{array}$}} & \multicolumn{2}{|c|}{ 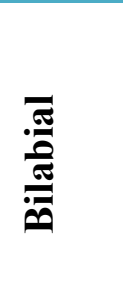 } & \multicolumn{2}{|c|}{ 总 } & \multicolumn{2}{|c|}{ 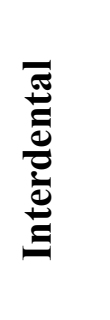 } & \multicolumn{2}{|c|}{$\begin{array}{l}\frac{i}{\pi} \\
\frac{0}{2} \\
\frac{2}{2}\end{array}$} & \multicolumn{2}{|c|}{ 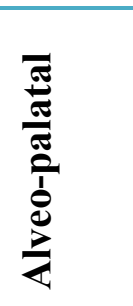 } & \multicolumn{2}{|c|}{$\begin{array}{l}\bar{\sigma} \\
\frac{\pi}{\pi} \\
\text { a }\end{array}$} & \multicolumn{2}{|c|}{$\frac{\dot{\bar{\sigma}}}{\bar{\nu}}$} & \multicolumn{2}{|c|}{ 离 } & \multicolumn{2}{|l|}{ 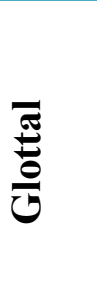 } \\
\hline & & E & $\mathrm{P}$ & E & $\mathrm{P}$ & $\mathrm{E}$ & $\mathrm{P}$ & E & $\mathrm{P}$ & E & $P$ & $\mathrm{E}$ & $\mathrm{P}$ & $\mathrm{E}$ & $P$ & $\mathrm{E}$ & $\mathrm{P}$ & $\mathrm{E}$ & $\mathrm{P}$ \\
\hline \multirow{2}{*}{ Stops } & $\mathrm{Vd}$ & $\mathrm{b}$ & $\mathrm{b}$ & & & & & $\mathrm{d}$ & $\mathrm{d}$ & & & & & $\mathrm{g}$ & $\mathrm{g}$ & & $\gamma$ & & $?$ \\
\hline & Vl & $\mathrm{p}$ & $\mathrm{p}$ & & & & & $\mathrm{t}$ & $\mathrm{t}$ & & & & & $\mathrm{k}$ & $\mathrm{k}$ & & & & \\
\hline \multirow{2}{*}{ Fricative } & $\mathrm{Vd}$ & & & $\mathrm{v}$ & $\mathrm{v}$ & ə & & $\mathrm{z}$ & $\mathrm{z}$ & 3 & 3 & & & & $\mathrm{x}$ & & & $\mathrm{h}$ & $\mathrm{h}$ \\
\hline & $\mathrm{Vl}$ & & & $\mathrm{f}$ & $\mathrm{f}$ & $\theta$ & & $\mathrm{s}$ & $\mathrm{s}$ & $\int$ & $\int$ & & & & & & & & \\
\hline \multirow{2}{*}{ Affricatives } & $\mathrm{Vd}$ & & & & & & & & & d3 & $d_{3}$ & & & & & & & & \\
\hline & Vl & & & & & & & & & t & $\mathrm{t} \int$ & & & & & & & & \\
\hline \multicolumn{2}{|l|}{ Nasals } & $\mathrm{m}$ & $\mathrm{m}$ & & & & & $\mathrm{n}$ & $\mathrm{n}$ & & & & & & & & & & \\
\hline \multicolumn{2}{|c|}{ Laterals } & & & & & & & 1 & 1 & & & & & & & & & & \\
\hline \multicolumn{2}{|c|}{ Vibrants } & & & & & & & $\mathrm{r}$ & $\mathrm{r}$ & & & & & & & & & & \\
\hline \multicolumn{2}{|c|}{ Semivowels } & $\mathrm{w}$ & $\mathrm{w}$ & & & & & & & & & y & $\mathrm{y}$ & & & & & & \\
\hline
\end{tabular}

As illustrated in Table 3, there are eight stops in Persian, including /p, b, t, d, k, g, y, R/, while English has only six stops, i.e. /p, b, t, d, k, g /. There are nine fricatives in English, while Persian has eight. Both languages have the same number of semivowels, liquids and affricates; however, it should be mentioned that the semi-vowel /w/ has a very limited distribution in Persian; in contrast to the Persian language, which has two nasals, there are three nasal sounds in English, including /m, n, y/. Some examples for phonetic signs of the Persian language are presented below: 
1. $/ \mathbf{p}^{\mathrm{h}} /$ : the initial sound in a word

Persian برنده

/pærænde/

'bird'

English 'pat'

2. $/ \mathbf{t}^{\mathrm{h}} /$ : the initial sound in a word

Persian

ترانه

/tærane/

'song'

English

'tosh'

3. $\quad / \mathbf{k}^{\mathrm{h}} /$ : the initial sound in a word

Persian

كوير

/kævir/

'desert'

English 'cot'

4. /b/: the initial sound in a word

Persian

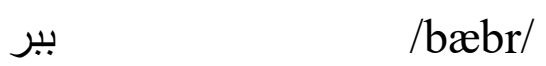

'tiger'

English

'bod'

5. /d/: the initial sound in a word

Persian

دنبا

/donia/

'world'

English

'down'

6. /2/: the initial sound in a word

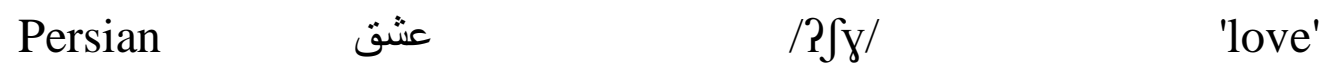

English

7. /3/: the initial sound in Persian and final sound in English

Persian

زاكت

/ 3pkæt/

'jacket'

English

'beige'

As can be seen in the examples 1, 2, and 3 above, the voiceless plosives /p, t, k/ are strongly aspirated in Persian. Example 6, i.e. / $\iint_{\gamma} /$, which means 'love', illustrates the post-velar/y/ and the glottal/?/ sound, which are both absent in English. 
On the other hand, vowels can be defined as speech sounds which are articulated without a substantial constriction of the airflow passing through the mouth; as one of the two general categories of the speech sounds classifications, i.e. vowels and consonants, vowels can be described as "sounds which are articulated without a complete closure in the mouth or a degree of narrowing which would produce audible friction; the air escapes evenly over the centre of the tongue" (Crystal 2008: 517). Roach (1991), in his book entitled "English phonetics and phonology" introduced eight vowels as primary cardinal vowels; a certain set of standard reference points in order to provide an accurate approach of recognizing the vowel sounds of languages based on a combination of auditory and articulatory considerations. He mentioned that these primary cardinal vowels are easily recognised in most of the European languages (Fig. 2):

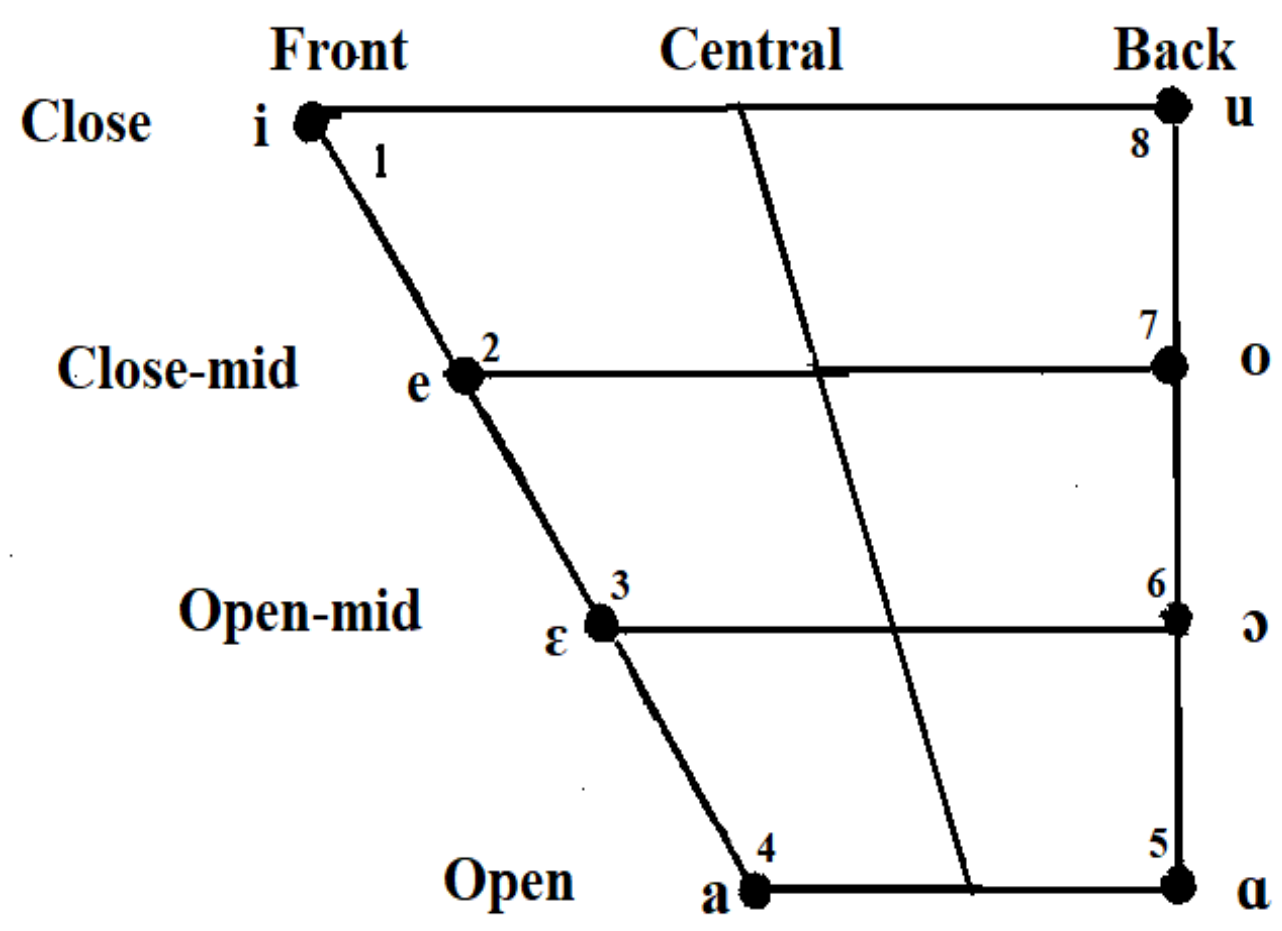

Figure 2. Primary cardinal vowels (Roach 1991: 13)

The following table illustrates the contrastive phonetic features of Persian and English vowels (Table 4). 
Table 4. Contrastive phonemic features of Persian and English vowels

\begin{tabular}{|c|c|c|c|c|c|c|c|}
\hline & \multicolumn{2}{|c|}{ FRONT } & \multicolumn{2}{|c|}{ CENTRAL } & \multicolumn{2}{|c|}{ BACK } \\
\hline & & $\mathbf{P}$ & $\mathbf{E}$ & $\mathbf{P}$ & $\mathbf{E}$ & $\mathbf{P}$ & $\mathbf{E}$ \\
\hline \multirow{2}{*}{ High } & Close & $\mathrm{i}$ & $\mathrm{i}$ & & & u & $\mathrm{u}$ \\
\hline & Open & & I & & & & $U$ \\
\hline \multirow{2}{*}{ Mid } & Close & $\mathrm{e}$ & & & & c & \\
\hline & Open & & $\varepsilon$ & & $\partial$ & & \\
\hline \multirow{2}{*}{ Low } & Close & & æ & & & & 0 \\
\hline & Open & $æ$ & & & $a$ & c & \\
\hline
\end{tabular}

As shown above in Table 4, there are six vowels in Persian. As Roach (1991) points out, English has eleven vowels, including five long and six short vowels, which differ in length and in quality. The following examples of phonetic signs of the Persian and English languages illustrate this.

First, some examples of phonetic signs for Persian vowels are presented below:

\begin{tabular}{|c|c|c|c|}
\hline 1. /i/ & سيم & /sim/ & 'wire' \\
\hline 2. /e/ & سل & /sel/ & 'tuberculosis' \\
\hline 3. $/ \mathfrak{a} /$ & سد & /sæd/ & 'dam' \\
\hline 4. $/ u /$ & خوب & /xub/ & 'good' \\
\hline $5 . / 0 /$ & رك & /rok/ & 'frank' \\
\hline $6 . / \mathrm{p} /$ & شاد & $/ \int \mathrm{pd} /$ & 'happy' \\
\hline
\end{tabular}

The following examples illustrate the phonetic signs for English vowels as presented in the International Phonetic Alphabet (IPA 1999: 42) 

1. /i/
heed
2. /I/
ship
3. $\mid \varepsilon /$
bed
4. /a/
cat
5. / / /
berth
6. /o/
hot
7. /u/
boot
8. /\%/
foot
9. /e/
bet
10. /a:/
father
11. / $/$
strut

As can be seen in the examples above, in contrast to English that has eleven vowels, in Persian there are six distinct vowels, out of which three are lax vowels, including /e/, $/ \mathrm{o} /, / \mathrm{p} /$, and three are tense vowels, i.e. $/ \mathrm{i} /, / \mathfrak{x} /, / \mathrm{u} /$.

\subsection{English and Persian diphthong vowels}

There are eight major diphthongs in the English language, including /eI/, /aI/, /oI/, /rə/, /eə/, / əə/, /əఠ/, and /av/ (Roach 1991); while there are six diphthongs in Persian, including /eI/, /aI/, /æi/ (less frequent), /oI/, /uI/, and /əø/. Table 5 and 6 respectively illustrate this.

Table 5. English diphthongs

\begin{tabular}{|c|c|}
\hline Diphthongs & Examples \\
\hline /ei/ & they; make \\
\hline /ai/ & I; by \\
\hline$/ \mathrm{I} /$ & boy; point \\
\hline /га/ & here; near \\
\hline /عכ/ & where; parent \\
\hline /ひə/ & tour; sure \\
\hline
\end{tabular}




\begin{tabular}{|c|c|}
\hline /ov/ & know; go \\
\hline lao/ & how; down \\
\hline
\end{tabular}

Table 6. Persian diphthongs

\begin{tabular}{|c|c|c|c|}
\hline Diphthongs & \multicolumn{3}{|c|}{ Examples } \\
\hline /eI/ & كى & /keI/ & 'when' \\
\hline /aI/ & جاى ج جإ & $/ \mathrm{t}$ fai/ & 'tea' \\
\hline /oI/ & رويا & /rora/ & 'dream' \\
\hline /æI/ & سيار & /sæıar/ & 'mobile' \\
\hline /ui/ & روى & /rui/ & 'zinc' \\
\hline /əठ/ & جو & /ృәу/ & 'barley' \\
\hline
\end{tabular}

As shown in Tables 5 and 6, besides some identical diphthongs in Persian and English, including /es/, /aI/, /oI/, /əv/, there are some other distinct diphthongs in these languages. For example, /гə/, /عə/, /๘ə/ are English diphthongs which cannot be found in the sound system of Persian, while, on the other hand, /æI/ and /uI/ are distinctive diphthongs in Persian; it should be mentioned, though, that these two diphthongs have a limited distribution in Persian.

\section{Discussion}

Based on the description of the phonological features of Persian and English, which is presented above, we observe that a Persian learner of English as a second/foreign language might transfer some phonological features of his/her native language into his/her second/foreign language. In the process, the learner might interpret certain sounds incorrectly and substitute English sounds with similar sounds of the Persian language. Such deviant phonological productions can be predicted. Some of deviant phonological productions of Iranian learners of English are summarized in the following Table 7. 
Table 7. Expected deviant phonological productions

\begin{tabular}{|c|c|c|}
\hline English & Deviant production & Description \\
\hline$/ \mathrm{t}, \mathrm{d} /$ & $/ \underline{\mathrm{t}}, \underline{\mathrm{d}} /$ & $\begin{array}{l}\text { Pronouncing English alveolar stops as dental } \\
\text { alveolar }\end{array}$ \\
\hline$/ \mathrm{s}, \mathrm{z} /$ & $/ \underline{\mathrm{s}}, \underline{\mathrm{z}} /$ & $\begin{array}{l}\text { Pronouncing English fricatives as dental } \\
\text { alveolar }\end{array}$ \\
\hline$/ \mathrm{n} /$ & $/ \underline{\mathrm{n}} /$ & Pronouncing English nasals as dental alveolar \\
\hline$/ /$ /ठ/ & /d/ or /z/ & $\begin{array}{l}\text { Substitution of /ð/ in English with /d/ or /z/ in } \\
\text { Persian, e.g., they is pronounced as } \boldsymbol{d e y} \text { or zay. }\end{array}$ \\
\hline$/ \theta /$ & $/ \mathrm{s} /$ or $/ \mathrm{t} /$ & $\begin{array}{l}\text { Substitution of } / \theta / \text { in English with } / \mathrm{s} / \text { or } / \mathrm{t} / \text { in } \\
\text { Persian, e.g., thanks is pronounced sanks or } \\
\text { tanks (more frequent) }\end{array}$ \\
\hline $\begin{array}{l}\text { Unaspirated } \\
/ \mathrm{p}, \mathrm{k}, \mathrm{t} /\end{array}$ & Aspirated $/ \mathrm{p}^{\mathrm{h}}, \mathrm{k}^{\mathrm{h}}, \mathrm{t}^{\mathrm{h}} /$ & $\begin{array}{l}\text { Aspirating the English unaspirated unvoiced } \\
\text { stops, e.g., the aspiration of } / \mathrm{k} / \text { in } \boldsymbol{s k i} \text { is } \\
\text { pronounced as /esk } \boldsymbol{k}^{\boldsymbol{h}} \text { / or / } \boldsymbol{s} \boldsymbol{s}^{\boldsymbol{h}} \boldsymbol{i} \text { / }\end{array}$ \\
\hline$/ \mathrm{w} /$ & $/ \mathrm{v} /$ & $\begin{array}{l}\text { Pronouncing English semivowel bilabial /w/ as } \\
\text { labiodentals / } / \text { at the initial sound of the word, } \\
\text { e.g., window is pronounced as vindow }\end{array}$ \\
\hline $\begin{array}{l}\text { Initial } \mathrm{CC}- \\
\text { clusters such as } \\
\text { /sk, sp, st, sl, sm, } \\
\text { sn/ }\end{array}$ & $\begin{array}{l}\text { /Psk, Psp, Pst, Psl, } \\
\text { Psm, Psn/ }\end{array}$ & 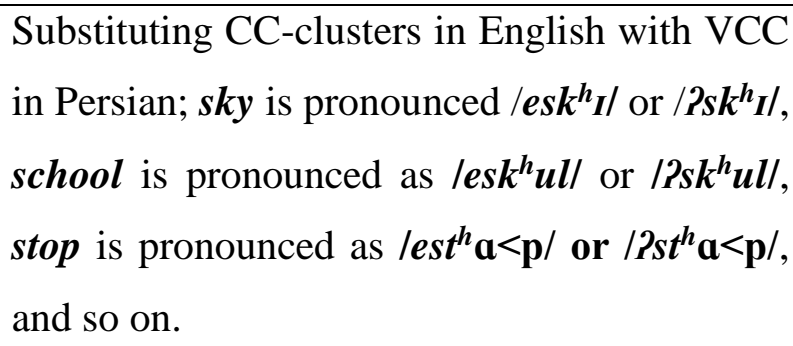 \\
\hline
\end{tabular}

Moulton (1962) states that when one investigates the phonological structure of a language, he/she needs to pay attention to the agreement between them, and then based on the observed dissimilarities between the languages, attempt both to predict the expected errors that language learners will make and also to explain why they will make these errors. In the case of Persian and English, as seen in Table 7, the following should be pointed out:

- A Persian-English bilingual speaker will be inclined to carry over and transfer his/her phonetic habits into English and use them as incorrect phones, for example: 
a) Substitution of $/ \mathrm{r} /$, which is retroflex in English, with $/ \mathrm{r} /$ that is flap and trill in Persian;

b) Substitution of alveolar consonants in English with dental alveolar consonants in Persian.

- A Persian-English bilingual speaker will be inclined to carry over and transfer his/her allophonic habits into English, which will result in incorrect English phones or phonemes, for example:

a) Substitution of $/ \mathrm{y} /$ in English with / $\mathrm{gg}$, $\mathrm{yk} /$ in Persian;

b) Substitution of $/ \mathrm{t}^{\prime} /$ (velarized lateral) in English with /l/ (dental alveolar) in Persian;

c) Substitution of $/ \mathrm{k}, \mathrm{g} /$ in English with $/ \mathrm{k}^{\mathrm{j}}, \mathrm{g}$ / (strongly palatalized velar stops) in Persian.

- As mentioned above in Table 7, a Persian-English bilingual speaker will be inclined to carry over and transfer his/her distributional habits into English and produce incorrect English phonemes, for example:

a) Substitution of initial CC-clusters in English /sk-, sp-, st-, sl-, sm-, sn-/ with VCC lesk-, esp-, est-, esl-, esm-, esn-/;

b) Substitution of initial CC-clusters in English such as /br-/, /tr-/, /kl-/, etc., with CVC in Persian /ber-, ter-, kel/, etc.

As discussed above, in CA, linguists and language experts compare the linguistic systems of two or more languages or language varieties, for instance, the grammatical features or sound systems of two particular languages. The following assumptions are significant in CA: 
a) Interference from L1 is one of the primary challenges in learning a second/foreign language;

b) These difficulties, however, can be predicted by CA;

c) Language teachers can use $\mathrm{CA}$ as a teaching material in order to diminish the effects of language interference, specifically, the negative transfer, which finally results in production of deviant structures, in errors or inappropriate/incompatible linguistic forms in the target language.

From the discussion it follows that some particular types of native language speech habits and articulations of Persian should be avoided and those which occur in the target language should be cultivated. For instance, as illustrated above, Iranian learners of the English language may need to avoid adding an extra vowel to the consonant clusters at onset position, such as /esk-, esp-, est-/ and /ber-, kel/ and so on, and they may also need to avoid strong palatalized velar stops of Persian; in addition, they may need to develop the $/ \mathrm{r} /$ as a retroflex sound in English instead of the flap or trill $/ \mathrm{r} / \mathrm{in}$ Persian.

\section{Conclusions}

Different languages have different phonological systems; they have different methods of distinguishing between their vowels and consonants. Our paper aims at providing a descriptive qualitative analysis of vowels and consonants in English and Persian, presenting a contrastive analysis of vowels and consonants of these languages, elaborates more on the contrasting phonological features of the two sound systems, which cause production of deviant structures by Iranian learners of English.

It should be mentioned that, though the main objective of the present study is a linguistic investigation of Persian and English sound systems through a contrastive analysis of the phonological features of the two languages, we assert that the pedagogical application of the results of the paper cannot be overlooked, because teaching correct pronunciation is very significant in English language education, and 
therefore the results of our study are expected to contribute both theoretically and practically to other researchers and linguists and language teachers.

Due to distinct phonological features of Persian and English, Iranian learners of the English language might misinterpret some sounds of English, as the target language, with their counterparts or similar sounds in their native language, i.e. Persian, which finally results in deviant phonological productions or the mispronunciation of the words.

However, it should be mentioned that although the above presuppositions or generalizations of deviant phonological productions by Persian-English bilingual speakers are interesting and significant, such kinds of deviant productions might not be commonplace or always true for all Iranian learners of English. In other words, this should not convey the idea that all language learners go through these deviant phonological productions; sound transfer in language production is a very sophisticated phenomenon and it involves a complicated process that has different forms under various contexts.

Knowledge of these distinct phonological features of Persian and English and the expected deviant phonological structures can help language teachers clarify the main phonological differences of the languages and help their students grasp these phonological differences between languages, produce the speech sounds accurately and finally pronounce the words correctly without misinterpretation of the sounds.
Abbreviations
CA - Contrastive analysis
IPA - International Phonetic Alphabet 


\section{References}

Bartholomae, C. (1883). Handbuch der altiranischen Dialekte. Leipzig: Druck und Verlag von Breitkopf \& Härtel.

Brown, H.D. (2000). Principles of language learning and teaching. London: Longman.

Catford, J.C. (1988). A practical introduction to phonetics. Oxford: Oxford University Press.

Chang, F.C. (2004). Chinese-speaking EFL learners' performances of processing English consonant clusters. In International conference on English instruction and assessment, 2004, National Chiayi University, p. 49-60.

Cheng, S. (2018). A contrastive analysis of word formation of English and Chinese neologisms. In Theory and practice in language studies, 8 (2), p. 251-256.

Crystal, D. (1969). Prosodic system and intonation in English. Cambridge: Cambridge University Press.

Crystal, D. (2008). A dictionary of linguistics and phonetics. Malden: Basil Blackwell Publishers.

Deterding, D. (2018). Prosodic typology II: The phonology of intonation and phrasing. Oxford: Oxford University Press.

Eghlidi, M. (2016). Contrastive analysis of English and Persian intonation patterns: An error analysis study on Iranian undergraduate EFL students. In Journal of applied linguistics and language research, 3 (4), p. 88-102.

Esteve-Gibert, N., Lœvenbruck, H., Dohen, M. et al. (2018). Head movements highlight important information in speech: An EMA study with French speakers. In Proceedings of XIV AISV conference on Speech in natural context 2018 (25-27 January, 2018, Bozen-Bolzano), p. 1-3. DOI: 10.13140/RG.2.2.21796.78727

Fasold, R.W. \& Connor-Linton, J. (2006). An introduction to language. Cambridge: Cambridge University Press.

Fernandez, I.O. \& Banguis, R.M. (2018). Contrastive analysis on the linguistic and rhetorical patterns of L1 and L2 writings of Cebuano ESL learners. In Asian EFL journal, 20 (2), p. 110-124. 
Forsberg, J. \& Abelin, Å. (2018). Intonation and levels of agreement in interactions between Swedish adolescents. In Proceedings of the $9^{\text {th }}$ international conference on speech prosody 2018 (13-16 June, 2018, Poznań, Poland), p. 55-59.

Goodwin, J. (2001). Teaching pronunciation. In Teaching English as a second or foreign language. $3^{\text {rd }}$ ed. Celce-Murcia, M. (ed.). Boston: Heinle \& Heinle, p. 117-137. Hayati, A.M. (1998). A contrastive analysis of English and Persian intonation. In Poznan studies in contemporary linguistics, 34, p. 53-72.

Hayati, A.M. (1996). A contrastive analysis of English and Persian intonation patterns. In Journal and proceedings of the Royal society of New South Wales, 129, p. 85-86.

Hayati, A.M. (2005). The methodology of teaching English intonation: A general perspective. In Journal of the faculty of literature and humanities, 1 (3), p. 79-102.

Hellmuth, S. (2018). Review of intonation in Romance. In Journal of Portuguese linguistics. Frota, S. \& Prieto, P. (eds.). Oxford: Oxford University Press, 17 (1), 3, p. 1-6. DOI: https://doi.org/10.5334/jpl.194

International Phonetic Association (1999). Handbook of the International Phonetic Association: A guide to the use of the International Phonetic Alphabet. Cambridge: Cambridge University Press.

Kabak, B. \& Idsardi, W.J. (2007). Perceptual distortions in the adaptation of English consonant clusters: Syllable structure or consonantal contact constraints? In Language and speech, 50 (1), p. 23-52. DOI: http://dx.doi.org/10.1177/00238309070500010201 Keshavarz, M.H. (2001). A practical course of English phonetics and phonology. Tehran: Scientific and Cultural Publications Company.

Khalifa, M.F. (2018). Contrastive analysis, error analysis, markedness theory, universal grammar and monitor theory and their contributions to second language learning. In International journal of linguistics, 10 (1), p. 12-45.

Knowles, G. (1987). Patterns of spoken English. Longman: London.

Mahjani, B. (2003). An instrumental study of prosodic features and intonation in Modern Farsi (Persian). MA thesis. Edinburgh: University of Edinburgh.

Melchers, G. \& Shaw, P. (2013). World Englishes. London: Routledge. 
Moradi, H. (2012). Sound deletion in colloquial Persian. In Modern journal of applied linguistics, 4 (3), p. 109-118.

Moulton, W.G. (1962). Toward a classification of pronunciation errors. In The modern language journal, 46 (3), p. 101-109.

Peters, J. (2018). Phonological and semantic aspects of German intonation. In Linguistik online, 88 (1), p. 85-108.

Puga, K., Fuchs, R., Hudson, T. et al. (2018). The perception-production link in intonation: Evidence from German learners of English. In Proceedings of the $9^{\text {th }}$ international conference on speech prosody 2018 (13-16 June, 2018, Poznań, Poland), p. 685-689.

Ranta, G. (2010). Language education today: Between theory and practice. Ranta, G. (ed.). Cambridge: Cambridge Scholars Publishing.

Richards, J.C. \& Schmidt, R W. (2013). Longman dictionary of language teaching and applied linguistics. London: Routledge.

Roach, P. (1991). English phonetics and phonology. Cambridge: Cambridge University Press.

Salmani Nodoushan, M.A., \& Birjandi, P. (2005). An introduction to phonetics. Tehran: Zabankadeh publications.

Soltani, A.M. (2007). Contrastive analysis of English and Persian intonation. Tehran: Iran University Press.

Tsui, R.K.Y. \& Tong, S.X. (2018). An acoustic study on the effect of the interaction between intonation and lexical tones on the realization of Cantonese sentence-final particles. In Proceedings of the $9^{\text {th }}$ international conference on speech prosody 2018 (13-16 June, 2018, Poznań, Poland), p. 45-49.

Vennemann, T. (1972). Phonetic detail in assimilation: Problems in Germanic phonology. In Language, pp. 863-892.

Yarmohammadi, L. (2002). A contrastive analysis of Persian and English: Grammar, vocabulary and phonology. Tehran: Payame Noor University Press.

Yule, G. (2006). The study of language. Cambridge: Cambridge University Press. 


\begin{tabular}{|c|c|c|}
\hline \begin{tabular}{l}
\multicolumn{1}{c}{ Contact data } \\
Hamzeh Moradi \\
\multicolumn{1}{c}{ PhD in Linguistics } \\
Associate Professor \\
Nanfang College of Sun \\
Yat-sen University, \\
Venquan Avenue, \\
Guangzhou, 510970, \\
Guangdong Province, \\
China e-mail: \\
hamzeh.m701@yahoo.com
\end{tabular} & & $\begin{array}{l}\text { Linguistics, } \\
\text { sociolinguistics, } \\
\text { applied linguistics, } \\
\text { language contact, } \\
\text { TESOL/TEFL, } \\
\text { language and } \\
\text { technology. }\end{array}$ \\
\hline \begin{tabular}{l}
\multicolumn{1}{c}{ Contact data } \\
Jianbo Chen \\
PhD in Education \\
Associate Professor \\
Sun Yat-sen University, \\
Xingang Xi Road, \\
Guangzhou, 510275, \\
Guangdong Province, \\
China e-mail: \\
736.4281.2@qq.com
\end{tabular} & Hent & $\begin{array}{l}\text { Fields of interest } \\
\text { Linguistics, } \\
\text { TESOL/TEFL, } \\
\text { applied linguistics, } \\
\text { language and } \\
\text { technology, } \\
\text { curriculum } \\
\text { development. }\end{array}$ \\
\hline
\end{tabular}

\section{Résumé}

Our study aims to investigate the phonological features of Persian and English as two typological and phonological different languages. It presents a contrastive analysis of two sound systems, namely, those of Persian and English. The paper renders a detailed descriptive analysis and a contrastive study of consonants and vowels of these languages, elaborating on the similar and dissimilar features of the two sound systems, which may result in production of deviant sounds by Persian-English bilingual speakers and language learners. We believe that the findings of this study can also be used in teaching English to the speakers of Persian, for the fact that language learners in the process of learning a second language (L2) may overgeneralize the phonological features and patterns of their native language into the target language, resulting in pronunciation errors and production of deviant phonetic forms. In other words, as a result of distinct phonological features of Persian and English, Iranian learners of English might misinterpret certain sounds of English with their counterparts in their 
native language, which finally results in deviant phonological productions or the mispronunciation of the words. Based on the contrastive analysis of Persian and English sound systems and the observed dissimilarities between them, the study provides some predictions about the possible errors of Iranian learners of English. For example, a Persian-English bilingual speaker will be inclined to transfer his/her native phonetic habits into English and use them as incorrect phones; s/he may also carry over his/her native language allophonic and distributional habits into English. Therefore, we hope such kind of contrastive study of Persian and English sound systems can theoretically and practically contribute to the existing research and significantly help linguists, researchers in the field and as well language teachers who engage in teaching English to the speakers of Persian.

Keywords: contrastive analysis, sound system, phonological features, consonants, vowels, bilingual speakers.

Article was received by the editorial board 5.11.18;

Reviewed 16.11.2018 and 21.11.18.

Similarity Index $10 \%$ 